\title{
Teacher's Engagement at Work: The Role of Future Time Perspective and Challenge Demands
}

\author{
Gustriani utami ${ }^{1}$, Debora E. Purba ${ }^{2}$, Dyah triarini indirasari ${ }^{3}$ \\ Faculty of Psychology, Universitas Indonesia ${ }^{1,2,3}$ \\ \{eflina@ui.ac.id $\left.{ }^{1}\right\}$
}

\begin{abstract}
This study aims to examine challenge demands as the mediator in the relationship between future time perspective (FTP) and work engagement. Based on the Conservation of Resources (CoR) theory, we expected that personal resource as manifested by FTP would increase challenge demands, which in turn would increase work engagement. Data were collected from convenience samples of middle school teachers $(N=200)$ and were tested using regression analysis. Results showed that challenge demands mediated the relation between FTP and work engagement $(\beta=.39, S E=.08,95 \% C I[.24 ; .55])$. Specifically, teachers with high FTP perceived their workload and responsibility as challenging, which increased their engagement in their work. Our findings contribute to the literature by showing that demands can turn into positive outcomes if they are considered as challenges, and that challenge demand serves as an underlying mechanism of the association between FTP and work engagement.
\end{abstract}

Keywords: FTP, Engagement, Demands

\section{Introduction}

Organizational sustainability is determined by the levels of work engagement of its employees. Work engagement is defined as a positive state of mind regarding work through vigor, dedication, and absorption [1]. Vigor is a high energy level and mental resilience at work, reflecting the willingness of an employee to invest effort in his or her job and persistence in dealing with difficulties. Dedication is defined as feelings of enthusiastic, inspired, and deep involvement in work activities[1]. Finally, absorption is the feeling of difficult to escape from work because of concentration and immersion in work that makes time pass quickly[1].

In the systematic review of 214 studies relevant to work engagement, Bailey, Madden, Alfes, and Fletcher [2] found 42 studies examining work engagement and performance relationships and 47 studies that examine the relationship between work engagement and morale, such as well-being, health perceptions, and work-related attitudes. Previous studies have identified several factors of work engagement [2] that can be categorized into five broad factors. The first factor is related to the individual psychological status, such as resilience[3]. Second is the aspects of job design in the form of job demands and job resources[4]. The third is management leadership factors, such as leader's assertiveness[5]. The fourth factor comprises individual perceptions of organizational support [6]. The fifth factor pertains to the 
organization's intervention programs, such as management by objective (MBO)program [7]. Of the five factors, the current study focuses on the personal resources that are assumed to belong to the individual's psychological status (i.e., time perspective).

Many scholars have proposed a theory of time perspective. One such theory defines a time perspective (TP) as an unconscious and relatively stable individual orientation [8]. TP has five dimensions, namely past-positive, past-negative, present fatalistic, present hedonistic, and future time perspective[8]. However, the present study focuses only on future time perspective (FTP) because individuals with FTP are predicted to be more enthusiastic, dissolved, and engaged in their work. FTP is a time perspective that individuals possess based on their future orientation, in that they have strong ambitions, do not waste their time to engage, and are willing to struggle in the present to achieve the desired goals[8]. This is in line with the characteristics of work engagement, in that individuals who are engaged are those who are immersed in their work[9].

Earlier studies on the relationship between FTP and work engagement [10]-[12] have found varying results. The coefficient correlations between FTP and work engagement are found to be moderate (physical $(r=.22)$, emotional $(r=.48)$, and cognitive $(r=.31)$ engagement, [12]; $r=.31,[11])$. The results indicate that the underlying mechanism between FTP and work engagement exists. We further draw on the Conservation of Resources (CoR) theory [13]to explain the psychological mechanisms for the relationship between FTP and work engagement. According to CoR theory, the individual will obtain, protect, and develop his or her resources to avoid a threatening situation [13]. Individuals with high FTP have clear future goals and plans to achieve them, therefore enabling them to see demands at work as challenges.

Job demands are representations of the physical, social and organizational aspects of work that require both physical and psychological effort [14]. Many previous studies have concluded that job demands are related to burnout and not to work engagement[9], [14]. In contrast to the aforementioned studies, Crawford, LePine, and Rich [16] in their meta-analysis study found that job demands, consisting of workload, time pressure, and responsibility[16]wererelated to positive work outcomes such as engagement[15]. Demands that are considered as challenges in work have the potential to enhance skills, personal development, and future benefits [15]so that everyone is more motivated to stick to his or her work.

As an example, teachers are required to conduct at least 24 hours of teaching time in 5-6 school days and engage in a handful of other tasks such as creating a teaching syllabus and evaluating student learning outcomes. The high workload helps teachers to achieve their goals, which include providing the best education and support for their students [17]that what may seem like a burden becomes a challenge instead. Teachers also have additional specific responsibilities within their work, such as teaching students according to their own unique needs, mentally preparing students for exams, and improving students' knowledge and skills. Any responsibility that teachers deem challenging can motivate them to commit and be engaged in the workplace.

Previous studies showed that teachers tend to perceive their daily challenge demands as effortful, rewarding, and meaningfully aligned with their values and interests, which in turn is related to their daily autonomous work motivation, and leads to higher daily work engagement [18]. Using the CoR theory, researchers of the current study argue that high FTP individuals have clear future goals and plans which act as their resources, such that would enable them to perceive job demands as challenge demands. Thus, challenge demands would, in turn, engage 
individuals to their job because they feel energized and vigorous that they immerse themselves to tackle the challenge. Based on the above argumentation, we hypothesize that:

"Challenge demands will mediate the relationship between future time perspective and work engagement".

\section{Method}

We used convenience sampling to collect the data at junior high schools in Banten, Indonesia. Participants were assured that their participation was confidential and voluntary. Of the 318 questionnaires distributed, a total of 220 questionnaires (response rate $=69 \%$ ) were returned. However, only 200 datasets were used in the final analysis, as the remaining 20 did not meet the required respondent characteristics (e.g., having worked for less than one year). Most respondents were women $(78.5 \%)$, the average age was $43.06(S D=9.62)$, while the average tenure was 15.8 years $(S D=9.5)$.

All measurement instruments in this study were translated into Indonesian from English using a back-translation process [19].FTP was measured using the Zimbardo Time Perspective Inventory $[8], \alpha=.70$. The measurement of challenge demands was adapted fromKaratepe et.al[20], $\alpha=.78$. Work engagement was measured using a short version of Utrecht Work Engagement Scale-9 (UWES-9) [21], $\alpha=.89$.

\section{Result and discussion}

Listed in Table 2 are the descriptive statistics and correlations among all tested variables. Analysis of the correlation between FTP and challenge demands showed that both variables are significantly related $(r=.55, p<.001)$. Moreover, FTP also correlates with work engagement $(r=.48, p<.001)$ and challenge demandswas significantly correlated with work engagement $(r=.54, p<.001)$. We also analyzed the correlation of demographic variables and the three main variables of the study. The results showed that age has a significant correlation with FTP $(r=.19, p=.006)$ and work engagement $(r=.23, p=.001)$, but does not correlate with challenge demands $(r=.11, n s)$. In addition, tenure correlates significantly with FTP $(r$ $=.16, p=.023)$, challenge demands $(r=.16, p=.022)$, and work engagement $(r=.33, p$ $<.001)$.

Table 1. Means, Standard deviations, and Correlations for The Study Variables

\begin{tabular}{lccccccc}
\hline \multicolumn{1}{c}{ Variable } & $M$ & $S D$ & 1 & 2 & 3 & 4 & 5 \\
\hline 1. Age & 43.06 & 9.62 & - & & & \\
2. Tenure & 15.8 & 9.5 & $.82^{* *}$ & - & & \\
3. Future time perspective & 3.87 & .41 & $.19 * *$ & $.16^{*}$ & - & \\
4. Challenge demands & 4.24 & .47 & .11 & $.16^{*}$ & $.55^{* *}$ & - \\
5. Work engagement & 4.87 & .73 & $.23^{* *}$ & $.33^{* *}$ & $.48^{* *}$ & $.54 * *$ & - \\
\hline Notes. $M=$ Mean, $S D=$ standard deviation. & $* * p$ & $<.01$ (two-tail), ${ }^{*} p<.05$ (two-tailed), $N=$ \\
200.
\end{tabular}

To test our main hypothesis, we used a mediation regression analysis with Hayes's Process Macro on SPSS. The results showed that challenge demands significantly mediated the 
relationship between FTP and work engagement, $\beta=.39, S E=.08, p<.001, C I[.24 ; .55]$, therefore our data support the hypothesis [Figure 1].

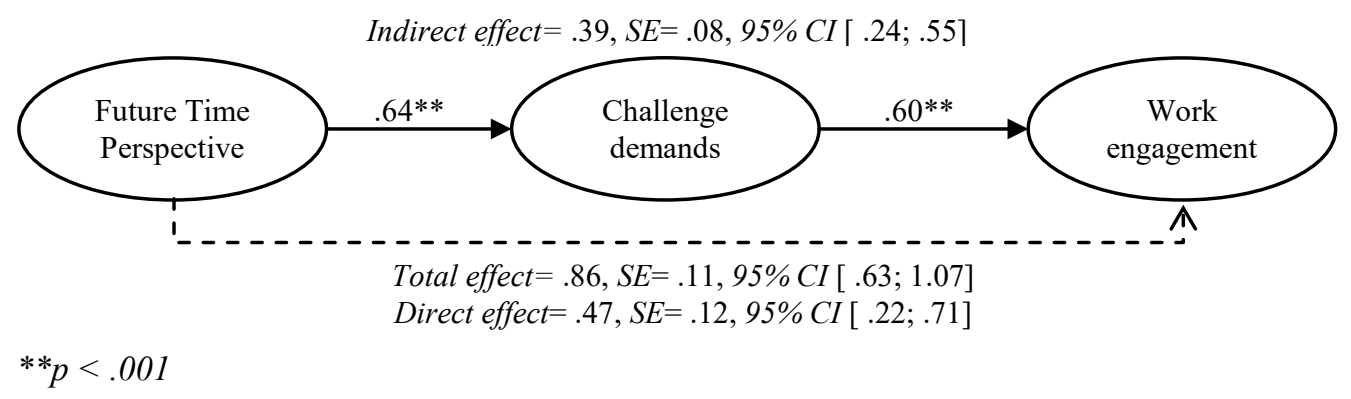

Figure 1. The Mediating Effect of Challenge Demands on the Relationship Between FTP and Work Engagement

Our study was in line with the CoR framework [13], in that high FTP individuals, who are characterized by having future goals and plans as resources, would commit themselves to achieve their goal by seeing their job demands as a challenge, and in turn, would engage themselves to the job. It also in line with the assertions of previous studies that job demands when considered as a challenge, can have a positive impact[10], [20]. This study has demonstrated that their time perspective, particularly by FTP, influences teachers who perceive their demand as challenging.

We contribute to the theoretical advancement by showing that teachers with high FTP can perceive work demands as challenge demands because they feel resourceful by having clear future goals. Indeed, teachers feel they have the responsibility for the success of their pupils, and having high responsibility is not burdensome for teachers. This, in turn, would lead to high levels of work engagement, because they are absorbed and dedicated to doing complete the challenges. When the workload and responsibility become high, teachers will not perceive them as a threat as long as it is required to accomplish their work goals [17], and it would turn into a positive outcome.

However, our findings suggested that challenge demands did not fully mediate the FTPwork engagement relationship. A possible explanation is that teachers being absorbed in their job is an indication that they have plans to achieve their goals and are determined to achieve them, yet they do not necessarily feel challenged in performing their job. Also, there may be an alternative mechanism that can better explain the pathway from FTP to work engagement. Previous research has reported that individuals with high FTPtend to craft their job in a way that increases work engagement [10].

The results of this study should help school principals and administrators recognize how potentially stressful demands can be considered as an opportunity to enhance positive emotions [15]. This finding suggests for educational institutions to promote FTP in their teachers using the Time Perspective Intervention [22]. It could enhance teachers' future orientation in accomplishing their goals and could enable them to see demands as a challenge, which in turn would increase their tendency to engage in their work.

The first limitation is we used a cross-sectional research design, implying that causality relations among variables cannot be determined. In the future, studies can perhaps improve our methods by using a longitudinal design. Second, the use of a self-report survey may have 
led to common method bias [23]. The result of Harman's single factor showed that the onefactor accounts for $30 \%$ of the total variance, indicating that common method variance was not a major problem. The third limitation concerns the fact that the negative impact of job demands on both challenge and hindrance (e.g., burnout) was not considered in this research. Thus, researchers of future studies should investigate the effects of both demands on burnout and work engagement. Finally, there are limitations in generalizing the results of this study as the sample consisted only of teachers. Therefore, it would need a further empirical examination of other working populations.

\section{Conclusion}

This study found that challenge demands partially mediated the relationship between FTP and work engagement. Our research contributes to the literature of work engagement by showing the underlying mechanism of challenge demands in FTP and work engagement relationship. This suggests that individuals with high FTP may feel energized, proud, and absorbed in their work if they perceive the demands as a challenge to be met.

Acknowledgments. This work is supported by Hibah PITTA 2018 funded by DRPM Universitas Indonesia No. 2347/UN2.R3.1/HKP.05.00/2018

\section{References}

[1] W. B. Schaufeli, M. Salanova, V. Gonzalez-Roma, and A. B. Bakker, "The measurement of engagement and burnout: A two sample confirmatory factor analytic approach," J. Happiness Stud., vol. 3, no. 1, pp. 71-92, 2002.

[2] C. Bailey, A. Madden, K. Alfes, and L. Fletcher, "The meaning, antecedents, and outcomes of employee engagement: A narrative synthesis," Int. J. Manag. Rev., vol. 19, no. 1, pp. 31-53, 2017.

[3] M. R. Santoso and D. Jatmika, "Hubungan resiliensi dengan work engagement pada agen asuransi PT X," J. Ecopsy, vol. 4, no. 2, pp. 117-123, 2017.

[4] A. Nurendra, "Peranan tuntutan kerja dan sumber daya kerja terhadap keterikatan kerja wanita karir," Psikologika J. Pemikir. dan Penelit. Psikol. J. Pemikir. dan Penelit. Psikol., vol. 21, no. 1, pp. 57-67, 2016.

[5] Y. R. Riandana and N. P. Noviati, "Perspesi terhadap asertivitas pimpinan dan keterikatan kerja karyawan,” Psikologika J. Pemikir. dan Penelit. Psikol., vol. 19, no. 2, pp. 111-120, 2014.

[6] A. I. Dwitasari, Ilhamuddin, and S. D. Widyasari, "Pengaruh perceived organizational support dan organizational-based self esteem terhadap work engagement," MEDIAPSI, vol. 1, no. 1, pp. 40-50, 2015.

[7] G. Utomo, B. Riyono, and S. Budiharto, "Efektifitas program management by objectives pada tingkat work engagement karyawan PT. X Ice Cream Yogyakarta," J. Ilm. Psikol. Terap., vol. 5, no. 2, pp. 210-225, 2017.

[8] P. G. Zimbardo and J. N. Boyd, "Putting Time in Perspective: A Valid, Reliable Individual-Differences Metric,” J. Pers. Soc. Psychol., vol. 77, no. 6, pp. 1271-1288, 1999.

[9] W. B. Schaufeli, “Applying the Job Demands-Resources model: A 'how to' guide to measuring and tackling work engagement and burnout," Organ. Dyn., vol. 46, no. 2, 
pp. 120-132, 2017.

[10] D. T. A. M. Kooij, M. Tims, and J. Akkermans, "The influence of future time perspective on work engagement and job performance: The role of job crafting," Eur. J. Work Organ. Psychol., vol. 26, no. 1, pp. 4-15, 2017.

[11] A. Schmitt, H. Zacher, and A. H. de Lange, "Focus on opportunities as a boundary condition of the relationship between job control and work engagement: A multisample, multi-method study," Eur. J. Work Organ. Psychol., vol. 22, no. 5, pp. 505519, 2013.

[12] S. K. Sia, B. C. Sahoo, and P. Duari, "Gender discrimination and work engagement: Moderating role of future time perspective," South Asian J. Hum. Resour. Manag., vol. 2, no. 1, pp. 58-84, 2015.

[13] S. E. Hobfoll, "Conservation of resources - A new attempt at conceptualizing stress," Am. Psychol., vol. 44, no. 3, pp. 513-524, 1989.

[14] A. B. Bakker and E. Demerouti, "Job Demands-Resources Theory," in Wellbeing, Chichester, UK: John Wiley \& Sons, Ltd, 2014, pp. 1-28.

[15] E. R. Crawford, J. A. LePine, and B. L. Rich, "Linking job demands and resources to employee engagement and burnout: A theoretical extension and meta-analytic test," $J$. Appl. Psychol., vol. 95, no. 5, pp. 834-848, 2010.

[16] M. A. Cavanaugh, W. R. Boswell, M. V Roehling, and J. W. Boudreau, “An empirical examination of self-reported work stress among U. S. managers," J. Appl. Psychol., vol. 85, no. 1, pp. 65-74, 2000.

[17] M. Tadić, A. B. Bakker, and W. G. M. Oerlemans, "Challenge versus hindrance job demands and well-being: A diary study on the moderating role of job resources," $J$. Occup. Organ. Psychol., vol. 88, no. 4, pp. 702-725, 2015.

[18] M. Tadić Vujčić, W. G. M. Oerlemans, and A. B. Bakker, "How challenging was your work today? The role of autonomous work motivation," Eur. J. Work Organ. Psychol., vol. 26, no. 1, pp. 81-93, 2016.

[19] D. E. Beaton, C. Bombardier, F. Guillemin, and M. B. Ferraz, "Guidelines for the process of cross-cultural adaptation of self-report measures," Spine (Phila. Pa. 1976)., vol. 25, no. 24, pp. 3186-3191, 2000.

[20] O. M. Karatepe, E. Beirami, M. Bouzari, and H. P. Safavi, "Does work engagement mediate the effects of challenge stressors on job outcomes? Evidence from the hotel industry," Int. J. Hosp. Manag., vol. 36, pp. 14-22, Jan. 2014.

[21] W. B. Schaufeli, A. B. Bakker, and M. Salanova, "The measurement of work engagement with a short questionnaire: A cross-national study," Educ. Psychol. Meas., vol. 66, no. 4, pp. 701-716, 2006.

[22] L. Ferrari, L. Nota, and S. Soresi, "Evaluation of an intervention to foster time perspective and career decidedness in a group of Italian adolescents," Career Dev. $Q$., vol. 60 , no. 1, pp. 82-96, 2012.

[23] P. M. Podsakoff, S. B. MacKenzie, J. Y. Lee, and N. P. Podsakoff, "Common method biases in behavioral research: A critical review of the literature and recommended remedies," J. Appl. Psychol., vol. 88, no. 5, pp. 879-903, 2003. 